\title{
Impact of COVID-19 pandemic on dental academia. Students' experience in online education and expectations for a predictable practice.
}

\section{Susan Hattar ( $\sim$ susanhattar@yahoo.fr)}

The University of Jordan

Abeer AlHadidi

The University of Jordan

Faleh A Sawair

The University of Jordan

Islam Abd Alraheam

The University of Jordan

Ahmad El-Ma'aita

The University of Jordan

Fouad Kadim Wahab

The University of Jordan

\section{Research Article}

Keywords: COVID-19, dental education, online learning, preparedness

Posted Date: August 6th, 2020

DOl: https://doi.org/10.21203/rs.3.rs-54480/v1

License: (9) (i) This work is licensed under a Creative Commons Attribution 4.0 International License. Read Full License

Version of Record: A version of this preprint was published at BMC Medical Education on August 6th, 2020. See the published version at https://doi.org/10.1186/s12909-021-02584-0. 


\section{Abstract}

\section{Abstract}

Background: The quarantine associated with the COVID-19 pandemic forced dental schools to suspend their clinical training and to shift to distant learning methods. The aim of this study is to investigate the impact of COVID-19 quarantine on the preparedness of dental graduates and to explore the efficacy and limitations of online education from students' perspectives.

Methods: the questionnaire distributed to dental students comprised of two main sections; first part covered the online education experience and the second part measured the level of preparedness for a range of cognitive, communication and professional skills.

Results: the survey yielded a response rate of $72 \%$. The majority of students $(77 \%)$ agreed that they missed educational experiences as a result of the lockdown. More than half of them felt less motivated in following-up with distant e-learning and believed that online assessment is not a good method for evaluation. A high percentage of the students $(66 \%)$ thought that online group discussions has a positive value whilst $67 \%$ preferred online lectures compared to theatre lectures. Majority of students particularly 5th year $(78.7 \%)(p<0.001)$ stated that the quarantine increased their collaboration with their colleagues. According to $87 \%$ of students, the experience most negatively affected was their clinical training.

In general, students showed satisfactory preparedness related to a range of attributes and professional skills, however, nearly two-thirds of them prefer to be mentored and favor a structured year of residence.

Conclusions: Data showed that students partially appreciated the online system, whereas they did not consider it a substitute for face to face clinical practice. The overall preparedness level was promising, however, some skills regarding evidence-based practice need consolidation. Students had reservations regarding independent practice following graduation.

\section{Background}

The gravity of Covid-19 pandemic has led governments and institutions to take draconian measures with regards to the ongoing education. In an attempt to balance the safeguarding of students, faculty, and patients, while keeping track of the changing national policies, universities were forced to take different measures to ensure the continuity of education. One of the biggest challenges has been to stop direct patient care, which is a key component of the dental curriculum. One cannot deny that didactic and clinical skills are two different outcomes of education. No virtual sessions can duplicate the close experience with patients [1]. In all situations, it remains the responsibility of dental schools to certify the competency of dental students, while being flexible to deviate from original curricular plan. Dental associations around the world have developed the frameworks for dental education that ensures finest 
academic practice for undergraduate education [2]. These councils define dentists as being scientifically oriented, professionally minded practitioner [3], who adhere to high standards of ethical and professional conduct and who can practice safely as a member of the healthcare system [4]. These criteria represent our baseline outcomes that cannot be compromised.

During the past few months, e-Learning had become our sole and only option to ensures the continuity of higher education. Fortunately, eLearning has proven to be a successful adjunct and has definitely impacted the environment in which medical students learn $[5,6,7,8,9]$. Our institution, as many others, started to embed the eLearning and blended learning into specific courses. Some disciplines seem to function well this way; however, this cannot be applied in its pure form for all subspecialties. For instance, in disciplines where patients' care is a primary goal, students need to attend clinics and provide patient treatment while acquiring their competencies. Although new technologies with simulation and virtual reality techniques are gaining more interest, still the direct in person experience is one that cannot be simply replaced.

On the other hand, distant learning has multiple facades that can undoubtedly improve education $[9,10]$. When compared to traditional didactic methods, the scientific material can be easily updated and rapidly accessed. Another advantage is that it can easily foster self-learning skills. Indeed, some studies have indicated that self-regulated learning, significantly affected academic achievement and learning performance [11]. For eLearning to be effective, staff development, assessment strategies and technological elements must be well planned and standardized. However, the sudden shift from traditional methods of teaching to a more creative distant learning did not allow sufficient time for adaptation. In our institution, clinical sessions have been suspended and we ended up finishing the scholastic year with a substantial degree of cut down on student clinical exposure by about $30 \%$ of their final years training. Question arises whether fulfilment of learning outcomes for general practice was established through the online experiences. Our students have missed out on many valuable opportunities, such as case presentations, OSCE exams, yearly faculty conference, in addition to their clinical sessions. Furthermore, dealing with psychological impact of this pandemic on students' mental wellbeing is another issue that should not be overlooked. Isolated in quarantine, students are with no doubt suffering from anxiety at different levels $[1,12,13]$. The fear of the unknown, the social distancing and the direct impact of COVID 19 on their future practice. We ask ourselves in what way students will perceive themselves in the real practical environment to evolve and integrate in their careers.

From another view, the general preparedness of dental students is influenced by many factors, such as curriculum design; training model; teaching methods and the overall educational environment. The keystone skills and attributes indispensable for graduation have been documented. Nevertheless, we do acknowledge that the current lack of adequate undergraduate training might reflect on the overall preparedness and confidence of our graduating students.

Resilience is the keyholder for success in these challenging times. To leverage technological advances to our benefit, implement new technologies that could raise the bar of education. Staff should also follow 
up with students to further help them consolidate their knowledge and facilitate their self-directed learning with innovative strategies. These approaches will help us circumvent the havocs to our benefit.

We believe that it is opportune time to reflect upon the effect of the pandemic on dental education and training. In this perspective, the aim of our study is to investigate the outcome of this shortened and modified scholastic year on the acquired skills and future aspirations of our graduating dental students. The second objective was to investigate the efficacy of distant learning from students' perspective and to pinpoint the attributes that were the mostly affected namely clinical, cognitive and behavioral skills. Furthermore, a preview of current challenges associated with distant education and possible futuristic reforms are discussed.

\section{Methods}

\section{Data collection}

At the end of scholastic year 2019-2020, all fifth-year graduates $(N=193)$ and fourth year $(N=239)$ dental students were asked to complete a questionnaire developed using (Qualtrics) before their final examinations. To maintain the anonymity, no personal identifiers were used in the online questionnaire. The introduction of the questionnaire defined the purpose and objectives of the study. The authors also stated clearly that participation is completely voluntary with no penalties associated with refusal or withdrawal from participation. Consent was implied by responding to the questionnaire.

The questionnaire comprised of two main themes/sections. The first section which was distributed to both fifth and fourth-year students was designed to investigate the students' attitudes regarding online learning. Questions were related to their educational experience with e-Learning, namely the efficacy of this system, their engagement level, their collaboration with colleagues, the value of this system in comparison with traditional methods and finally the assessment methods applied. At the end, data regarding the experience and the subspecialty which had the highest negative impact were gathered. The responses of this section were reported on a four-point scale Likert scale (strongly agree, agree, disagree, strongly disagree).

The second section investigated students self-perceived preparedness for dental practice. This part was distributed only to graduating students of the 2019-2020 batch ( $N=193)$. It had two main categories. The first category consisted of 17 questions derived from a previously validated scale [14] that explores a broad range of skills and attributes expected from dental students at the time of graduation. These 17 indicators of cognition, communication, and professional skills had 3 scales: "No experience" which was allocated a score of zero; "Mostly" allocated a score of one, and "Always" allocated a score of two. The total score for the preparedness scale ranged from 0 to 34 .

The second category focused on students' perceived readiness for dental practice with regards to confidence in skills acquired before graduation, preference to be monitored after graduation, readiness for independent practice and predilection for a well-structured year of residency. 


\section{Statistical Analysis}

Statistical analysis was performed using SPSS for Windows release 16.0 (SPSS Inc., Chicago, IL, USA). Descriptive statistics were generated, and Chi-square test and independent sample t-test were used to examine differences between groups. The significance level was stated as $P<0.05$.

\section{Results}

310 participants responded to the online questionnaire, yielding a response rate of $72 \%$. The study sample was composed of 179 (57.7\%) fourth year and 131 (42.3\%) fifth year dental students. They were composed of $241(77.7 \%)$ female and $69(22.3 \%)$ male students.

\section{Section 1: Impact on dental education. Students' attitudes towards Online Learning}

The educational impact of COVID-19 on 4th and 5th year dental students is shown in Table 1. 


\begin{tabular}{|c|c|c|c|c|c|c|c|}
\hline \multicolumn{2}{|c|}{ Question } & Year & $\begin{array}{l}\text { Strongly } \\
\text { disagree } \\
\%\end{array}$ & $\begin{array}{l}\text { Disagree } \\
\%\end{array}$ & \multirow{2}{*}{$\begin{array}{l}\text { Agree } \\
\% \\
49.7\end{array}$} & $\begin{array}{l}\text { Strongly } \\
\text { agree\% }\end{array}$ & p value* \\
\hline \multirow[t]{3}{*}{1} & \multirow{3}{*}{$\begin{array}{l}\text { Do you feel that you missed } \\
\text { educational experiences as a } \\
\text { result of the lockdown? }\end{array}$} & $4^{\text {th }}$ & 3.4 & 20.7 & & 26.3 & \multirow[t]{3}{*}{0.96} \\
\hline & & $5^{\text {th }}$ & 3.8 & 18.3 & 51.1 & 26.7 & \\
\hline & & Total & 3.5 & 19.7 & 50.3 & 26.5 & \\
\hline \multirow[t]{3}{*}{2} & \multirow{3}{*}{$\begin{array}{l}\text { Do you think online assessment } \\
\text { is a good method for evaluation? }\end{array}$} & $4^{\text {th }}$ & 22.9 & 43.0 & 30.2 & 3.9 & \multirow[t]{3}{*}{0.001} \\
\hline & & $5^{\text {th }}$ & 13.0 & 30.5 & 50.4 & 6.1 & \\
\hline & & Total & 18.7 & 37.7 & 38.7 & 4.8 & \\
\hline \multirow[t]{3}{*}{3} & \multirow{3}{*}{$\begin{array}{l}\text { Do you think group discussion } \\
\text { posted on E-learning such as } \\
\text { clinical cases and scenarios had } \\
\text { a positive value on your } \\
\text { education? }\end{array}$} & $4^{\text {th }}$ & 14.0 & 34.6 & 44.7 & 6.7 & \multirow[t]{3}{*}{$<0.001$} \\
\hline & & $5^{\text {th }}$ & 0.8 & 14.5 & 51.1 & 33.6 & \\
\hline & & Total & 8.4 & 26.1 & 47.4 & 18.1 & \\
\hline \multirow[t]{3}{*}{4} & \multirow{3}{*}{$\begin{array}{l}\text { Did this quarantine increase your } \\
\text { collaboration with your } \\
\text { colleagues? }\end{array}$} & $4^{\text {th }}$ & 6.1 & 41.9 & 33.5 & 18.4 & \multirow[t]{3}{*}{$<0.001$} \\
\hline & & $5^{\text {th }}$ & 1.5 & 19.8 & 55.0 & 23.7 & \\
\hline & & Total & 4.2 & 32.6 & 42.6 & 20.6 & \\
\hline \multirow[t]{3}{*}{5} & \multirow{3}{*}{$\begin{array}{l}\text { Did you feel more engaged and } \\
\text { motivated in following up with } \\
\text { distant e-learning? }\end{array}$} & $4^{\text {th }}$ & 19.6 & 39.1 & 30.2 & 11.2 & \multirow[t]{3}{*}{0.049} \\
\hline & & $5^{\text {th }}$ & 14.5 & 33.6 & 45.0 & 6.9 & \\
\hline & & Total & 17.4 & 36.8 & 36.5 & 9.4 & \\
\hline \multirow[t]{3}{*}{6} & \multirow{3}{*}{$\begin{array}{l}\text { Do you prefer online lectures } \\
\text { compared to face to face theatre } \\
\text { lectures? }\end{array}$} & $4^{\text {th }}$ & 10.1 & 27.4 & 38.5 & 24.0 & \multirow[t]{3}{*}{0.14} \\
\hline & & $5^{\text {th }}$ & 4.6 & 22.1 & 48.1 & 25.2 & \\
\hline & & Total & 7.7 & 25.2 & 42.6 & 24.5 & \\
\hline \multirow[t]{3}{*}{7} & \multirow{3}{*}{$\begin{array}{l}\text { Do you feel comfortable with all } \\
\text { this technology-based } \\
\text { education? }\end{array}$} & $4^{\text {th }}$ & 13.4 & 40.2 & 35.8 & 10.6 & \multirow[t]{3}{*}{$<0.001$} \\
\hline & & $5^{\text {th }}$ & 1.5 & 33.6 & 55.7 & 9.2 & \\
\hline & & Total & 8.4 & 37.4 & 44.2 & 10.0 & \\
\hline
\end{tabular}

${ }^{*} \mathrm{p}$ value of Chi square test.

Table 1. Educational impact of COVID-19 on $4^{\text {th }}$ and $5^{\text {th }}$ year dental students. 
The majority $(76.8 \%)$ of the students, without significant effects of gender or year of study, agreed that they missed educational experiences as a result of the lockdown.

More than half $(56.4 \%)$ of the students, particularly 4 th year $(65.9 \%)(p=0.001)$, feel that online assessment is not a good method for evaluation. Similarly, $54.2 \%$ of the students, particularly 4 th year $(58.7 \%)(p=0.049)$, feel less engaged and motivated in following-up with distant e-learning.

In contrast, higher percentage of the students $(65.5 \%)$, particularly 5 th year $(84.7 \%)(p<0.001)$, think that group discussion posted on e-learning such as clinical cases scenarios had a positive value on their education. Similarly, higher percentage of the students $(63.2 \%)$, particularly 5 th year $(78.7 \%)(p<0.001)$, think that the quarantine increased their collaboration with their colleagues. In addition, $67.1 \%$ of the students, without significant effects of gender or year of study, prefer online lectures compared to face to face theatre lectures. Significantly higher percentage of 5 th year $(64.9 \%)$ compared to 4 th year dental students $(46.4 \%)(p<0.001)$ feel comfortable with the technology-based education.

The experiences that were mostly affected by quarantine according to 4th and 5 th year dental students are shown in Figure 1. Clinical training was the mostly affected experience reported by students (86.5\%). Regular lectures were missed by a significantly higher percentage of 4 th year students $(p=0.008)$, while comprehensive case presentations were missed by higher percentage of 5 th year students $(p<0.001)$.

According to 4th and 5th year dental students, the dental subspecialties most negatively affected by quarantine are shown in Figure 2. Conservative dentistry (73.2\%) followed by prosthodontics (69.4\%) were the two most negatively affected subspecialties while orthodontics (18.4\%) and oral diagnosis $(21.0 \%)$ were the two least negatively affected subspecialties. Pediatric dentistry $(p=0.002)$ was reported to be negatively affected by higher percentage of 5 th year students, while oral surgery $(p=0.033)$, periodontics $(p<0.001)$, orthodontics $(p<0.001)$, and oral diagnosis $(p<0.001)$ were reported to be negatively affected by higher percentage of 4 th year students.

\section{Section 2: Preparedness related to cognition, communication, and professional skills}

The mean total preparedness score (TPS) for the 131 participants 5 th year students was 24.4 (SD \pm 4.7 ) with a range of 5 to 34 . The mean TPS was not significantly affected by gender of the participants $(p>0.05)$.

The responses of the students to the 17 indicators of preparedness related to cognition, communication, and professional skills are shown in Table 2. Generally, students showed a total or most of time preparedness related to majority of attributes and professional skills. However, a significant percentage of students find difficulty in evaluating new dental materials using evidence-based approach (47.3\%) and in having sufficient evidence-based knowledge of scientific principles to support their dental practice. In addition, around $10 \%$ of students do not reflect on their clinical practice in order to address their learning needs. 


\begin{tabular}{|c|c|c|c|c|}
\hline \multicolumn{2}{|c|}{ Skill } & \multirow{2}{*}{$\begin{array}{l}\text { No } \\
\text { experience } \\
\%\end{array}$} & \multirow{2}{*}{$\begin{array}{l}\text { Mostly } \\
\% \\
38.9\end{array}$} & \multirow{2}{*}{$\begin{array}{l}\text { Always } \\
\% \\
13.7\end{array}$} \\
\hline 1 & $\begin{array}{l}\text { I evaluate new dental materials/products using evidence- } \\
\text { based approach. }\end{array}$ & & & \\
\hline 2 & $\begin{array}{l}\text { I have sufficient evidence-based knowledge of scientific } \\
\text { principles to support my practice. }\end{array}$ & 19.1 & 66.4 & 14.5 \\
\hline 3 & $\begin{array}{l}\text { I reflect on my clinical practice in order to address my } \\
\text { learning needs. }\end{array}$ & 9.9 & 50.4 & 39.7 \\
\hline 4 & I can manage patient's expectations for their treatment. & 7.6 & 61.1 & 31.3 \\
\hline 5 & I am able to refer patients with complex treatment needs. & 6.9 & 30.5 & 62.6 \\
\hline 6 & $\begin{array}{l}\text { I feel comfortable asking for help from supervisor/colleague } \\
\text { if needed. }\end{array}$ & 6.9 & 46.6 & 46.6 \\
\hline 7 & I maintain accurate records of my clinical notes. & 4.6 & 50.4 & 45 \\
\hline 8 & $\begin{array}{l}\text { I restrict my relations with my patients to a professional } \\
\text { level. }\end{array}$ & 4.6 & 43.5 & 51.9 \\
\hline 9 & $\begin{array}{l}\text { I take responsibility for my continuing professional } \\
\text { development. }\end{array}$ & 3.8 & 33.6 & 62.6 \\
\hline 10 & $\begin{array}{l}\text { I take appropriate measures to protect patient } \\
\text { confidentiality. }\end{array}$ & 3.8 & 22.9 & 73.3 \\
\hline 11 & $\begin{array}{l}\text { I can communicate potential procedural risks to my } \\
\text { patients. }\end{array}$ & 3.1 & 47.3 & 49.6 \\
\hline 12 & I can obtain informed consent from my patients. & 2.3 & 31.3 & 66.4 \\
\hline 13 & $\begin{array}{l}\text { I can motivate my patients to maintain good oral/general } \\
\text { health. }\end{array}$ & 1.5 & 55 & 43.5 \\
\hline 14 & $\begin{array}{l}\text { I am aware of my legal responsibilities as a dental } \\
\text { professional. }\end{array}$ & 0.8 & 31.3 & 67.9 \\
\hline 15 & I recognize my personal limitations in clinical practice. & 0.8 & 39.7 & 59.5 \\
\hline 16 & I can communicate appropriately with my colleagues. & 0.8 & 26.7 & 72.5 \\
\hline 17 & I can communicate effectively with my patients. & 0 & 35.9 & 64.1 \\
\hline
\end{tabular}

Table 2. Preparedness related to cognition, communication, professional skills of $5^{\text {th }}$ year dental students arranged in descending order with regards to "No experience"

\section{General Practice readiness}

As shown in Table 3, nearly one-third of 5th year students are not sure of their confidence in the skills acquired before graduation and nearly two-thirds of them prefer to be mentored or indirectly supervised 
following graduation. In addition, only $28.2 \%$ have confidence in starting an independent practice after graduation and, therefore, the majority prefer to have a well-structured year of residence with proper training after graduation.

\begin{tabular}{|c|c|c|c|c|}
\hline \multicolumn{2}{|c|}{ Question } & $\begin{array}{l}\text { No } \\
\%\end{array}$ & $\begin{array}{l}\text { Unsure } \\
\%\end{array}$ & $\begin{array}{l}\text { Yes } \\
\%\end{array}$ \\
\hline & & & & \\
\hline 1 & Do you have confidence in the skills acquired before graduation? & 3.8 & 35.1 & 61.1 \\
\hline 2 & $\begin{array}{l}\text { Do you prefer to be mentored or indirectly supervised following } \\
\text { graduation? }\end{array}$ & 11.5 & 24.4 & 64.1 \\
\hline 3 & $\begin{array}{l}\text { Do you have confidence in starting an independent practice after } \\
\text { graduation? }\end{array}$ & 27.5 & 44.3 & 28.2 \\
\hline 4 & $\begin{array}{l}\text { Do you have preference for a well-structured year of residence, with } \\
\text { proper training? }\end{array}$ & 3.1 & 10.7 & 86.3 \\
\hline
\end{tabular}

\section{Table 3. Practice readiness of $5^{\text {th }}$ year dental students}

\section{Discussion}

The shock that the pandemic caused to the entire educational system was abrupt and unprecedented. With very short notice, we found ourselves unable to teach conventionally, left with unorthodox resources and limited possibilities. Multi-disciplinary approaches, clinical environments were abandoned, and teaching as we know it was suspended, with only one solution of being creative in an online environment. In many institutions, online teaching is still considered rudimentary while its clinical implementation is not evident, consequently teaching the medical clinical skills became the ultimate challenge.

Little evidence has been reported regarding the plausible impact of this pandemic on higher education. One study has shown that there could be a positive effect of the COVID-19 confinement on students' performance [15]. The authors concluded that the quarantine changed students' learning strategies to a more efficient productive routine with higher levels of engagement. Contrary to their results, the majority of our students sensed that they actually missed important learning experiences especially the clinical sessions and felt less engaged in following up with distant learning. This could be explained by the fact that the former study was related to education in basic sciences, whereas dentistry needs practice and ample clinical exposure. This new teaching methodology does not come without barriers and is definitely not suitable for all courses. Furthermore, participants stated that conservative dentistry was the subspecialty most negatively affected. This is comprehendible since the bulk of students' clinical exposure during their final years revolves around restorative dentistry. In a study which conducted focus group interviews with students to understand the contributing factors for a confident graduation.

Students from different schools confirmed that the most important factor affecting their preparation was indeed clinical exposure [16]. 
Growing evidence claims that e-Learning is as effective as traditional methods. One review investigating the barriers and enablers of e-learning concluded that it might enhance learning and performance due to its flexibility and accessibility [17]. Some studies have demonstrated higher satisfaction for e-learning methods and reported that many medical students find e-learning gratifying $[10,18]$. Comparatively, our students seem to appreciate online lectures and forum case discussions which might be due to the interactive nature of these components. However, this is a self-perceived satisfaction that does not necessarily reflect higher performance [6, 9].

Although the teaching and learning arms of education might not have been dramatically affected, it is the assessment part that had the highest fluctuation in this new distant scenario. During our final exams, summative assessments of clinical reasoning is usually performed through Objective Structured Clinical Examinations (OSCES). OSCE exams have been widely used in medical field and substitute a valid methodology with high educational value $[19,20]$. This year all on campus exams have been cancelled. From students' perspective, the online substitute assessments did not match the traditional methods for evaluation. One causal factor could be the lack of proper tools to facilitate the process such as flawless connections at their locations, in addition to the anxiety built up from lack of direct presence of the evaluators.

The success of distant learning relies not only on the students' motivation but on continuous interaction between learners and facilitators [17]. A synchronous collaboration might be the cornerstone to enhance their level of engagement [21]. Our students have noticed that the quarantine increased their interactions and collaboration especially with their classmates. This open communication that we witnessed between students and staff could have built the mutual trust and facilitated their cooperation. As educators, our role lies within encouraging the students to stay connected and follow up on their education. Clear directions should be given, and students should not be left in the dark when it comes to decisions that will directly affect their education.

On a range of cognitive and behavioral attributes our students were asked about their readiness for general dental practice. Our results show that self-perceived preparedness for graduating students was satisfactory for a wide range of affective skills and traits. Our students showed confidence in communication and continuous development, similarly to other studies [22, 23, 24, 25]. Nevertheless, there were several areas of weakness that require improvement especially those related to evidencebased practice. This conforms with studies performed in different worldwide institutions where evidencebased dentistry and critical appraisal skills were lacking $[14,24,26,27]$. We can still argue that the attitudes and knowledge of graduates may alter after embarking into the career world and their concerns might be overcome once they integrate into their practice.

Many studies have shown that dental students are usually confident in carrying out procedures safely, nevertheless felt somehow unprepared and still relied on some sort of supervision. ${ }^{25,28}$ Comparatively, one third of our students were not sure of the skills acquired before graduation and nearly two-thirds prefer to be indirectly supervised following graduation. Mentoring was considered very important and 
they still had some reservations in regard to independent dental practice. It might be related to their doubts about the amount of practice they experienced during their final years. One way to overcome this anxiety would be to expose our students outreach teaching experiences such as community dental care, for it proved to be a useful adjunct for clinical experience, communication skills as well as self-confidence $[29,30,31]$.

Navigating the challenges associated with this sudden shift, faculty members thrived to get the necessary training to use online platforms, yet not everyone has the same level of technological expertise. Not to mention, the necessary infrastructure and resources that are not always available to support this complete transition. Suddenly e-learning rose from an optional rudimentary choice to the only alternative at hands. We hope not to see this as a detriment to education but a learning experience giving way to a new generation of digital academia. Perhaps, this global change created the momentum for us all to exchange ideas and medical schools must share their practices and valuable experiences [21].

While new solutions such as simulation and virtual reality systems might be promising alternatives, reemerging is the key to overcome all challenges, for this pandemic allowed education to be reinvented.

\section{Conclusion}

Our role as academician is to evaluate and ensure the students' preparedness but it is equally important to understand work readiness from students' perspective. Confinement was a new setting they have never experienced before, and online learning was a unique pedagogical experience with distinct challenges. The data showed that students partially appreciated the new system with e-lectures and discussion forums, however they still believe that it was not a substitute for face to face clinical practice and they acknowledge missing many educational experiences. Fortunately, the overall preparedness level was promising, and students felt confident for majority of the attributes expected from dentists. However, some skills regarding evidence-based practice and knowledge need consolidation and additional emphasis. Their feedback also reflected their reservation toward independent practice following graduation. Future research of new pedagogic methodologies is warranted and investigating the correlation between academic performance and use of online resources might be beneficial.

\section{Declarations}

\section{Ethics approval and consent to participate}

The study protocol was reviewed and approved by the Institutional Review Board of Jordan University Hospital (Ref \# 75/2020/616). The introduction of the questionnaire defined the purpose and objectives of the study. The authors also stated clearly that participation is completely voluntary with no penalties associated with refusal or withdrawal from participation. Consent was implied by responding to the questionnaire.

\section{Consent for publication}

Page 11/16 
Not applicable.

\section{Availability of data and materials}

All data generated or analysed during this study are included in this published article.

\section{Competing interests}

There were no financial or professional interests that affected the study.

\section{Funding}

The authors declare they have no source of funding for the research.

\section{Authors' contributions}

SH was involved in designing the study and writing the manuscript. AA prepared the questionnaires and gathered data. FS performed data analysis and statistics. IAA participated in designing survey questions. AE participated in interpretation of data and discussion elements. FKW revised and proofread the manuscript. All authors have read and approved the final version of the manuscript.

\section{Acknowledgements}

Not applicable

\section{References}

1. Sahu P. Closure of Universities Due to Coronavirus Disease 2019 (COVID-19): Impact on Education and Mental Health of Students and Academic Staff. Cureus 2020;12(4):e7541.

2. Field JC, Cowpe JG, Walmsley AD. The Graduating European Dentist: A New Undergraduate Curriculum Framework. Eur J Dent Educ 2017;21Suppl 1:2-10.

3. McLoughlin J, Zijlstra-Shaw S, Davies JR, Field JC. The Graduating European Dentist-Domain I: Professionalism. Eur J Dent Educ 2017;21Suppl 1:11-3.

4. Gallagher J, Field JC. The Graduating European Dentist-Domain IV: Dentistry in Society. Eur J Dent Educ 2017;21:25-7.

5. Zitzmann NU, Matthisson L, Ohla H, Joda T. Digital undergraduate education in dentistry: A systematic review. Int J Environ Res Public Health 2020;17(9):3269.

6. Venkatesh Murthy S, Rao YK, Nagaraja H, Woolley T, Alele FO, Malau-Aduli BS. Factors influencing medical students' experiences and satisfaction with blended integrated e-learning. Med Princ Pract Dec 2019.

7. Fontaine G, Cossette S, Maheu-Cadotte MA, Mailhot T, Deschênes MF, Mathieu-Dupuis G, et al. Efficacy of adaptive e-learning for health professionals and students: A systematic review and meta- 
analysis. BMJ Open 2019;9(8):1-17.

8. Kim KJ, Kim G. Development of e-learning in medical education: 10 years' experience of Korean medical schools. Korean J Med Educ 2019;31(3):205-14.

9. Sadeghi R, Sedaghat MM, Sha Ahmadi F. Comparison of the effect of lecture and blended teaching methods on students' learning and satisfaction. J Adv Med Educ Prof 2014;2(4):146-50.

10. Huynh R. The Role of E-Learning in Medical Education. Acad Med 2017;92(4):430.

11. Zimmerman BJ, Kitsantas A. Comparing students' self-discipline and self-regulation measures and their prediction of academic achievement. Contemp Educ Psychol 2014;39(2):145-55.

12. Gillett-Swan J. The Challenges of Online Learning: Supporting and Engaging the Isolated Learner. J Learn Des 2017;10(1):20-30.

13. Li Y, Wang Y, Jiang J, Valdimarsdóttir UA, Fall K, Fang F, et al. Psychological distress among health professional students during the COVID-19 outbreak. Psychol Med 2020 May 11:1-3.

14. Ali K, Cockerill J, Zahra D, Qazi HS, Raja U, Ataullah K. Self-perceived preparedness of final year dental students in a developing country-A multi-institution study. Eur J Dent Educ 2018;22(4):e74550.

15. Gonzalez T, de la Rubia MA, Hincz KP, Comas-Lopez M, Subirats L, Fort S, et al. Influence of COVID-19 confinement in students performance in higher education. 2020. Available from: http://arxiv.org/abs/2004.09545

16. Ray M, Milston A, Doherty P, Crean S. In their own words: Investigating the preparedness of final year dental students in the UK for independent general dental practice. Br Dent J 2018;225(4):340-9.

17. Regmi K, Jones L. A systematic review of the factors - Enablers and barriers - Affecting e-learning in health sciences education. BMC Med Educ 2020;20(1):91.

18. Ruiz JG, Mintzer MJ, Leipzig RM. The impact of e-learning in medical education. Acad Med 2006;81(3):207-12.

19. Hammad M, Oweis Y, Taha S, Hattar S, Madarati A, Kadim F. Students' opinions and attitudes after performing a dental OSCE for the first time: a Jordanian experience. J Dent Educ 2013; 77(1):99-104.

20. Puryer J. Dental Undergraduate Views of Objective Structured Clinical Examinations (OSCEs): A Literature Review. Dent J 2016;4(1):6.

21. Taha $\mathrm{MH}$, Abdalla ME, Wadi $\mathrm{M}$, Khalafalla $\mathrm{H}$. Curriculum delivery in Medical Education during an emergency: A guide based on the responses to the COVID-19 pandemic. MedEdPublish 2020;9(1). https://doi.org/10.15694/mep.2020.000069.1

22. Ali K, Slade A, Kay E, Zahra D TC, Tredwin C. Preparedness of undergraduate dental students in the United Kingdom: a national study. Br Dent J 2017;24(6):472-77.

23. Ali K, Jerreat M, Zahra D, Tredwin C. Correlations between final-year dental students' performance on knowledge-based and clinical examinations. J Dent Educ 2017;81(12):1444-50.

24. Mat Yudin Z, Ali K, Wan Ahmad WMA, Ahmad A, Khamis MF, Brian Graville Monteiro NA, et al. Selfperceived preparedness of undergraduate dental students in dental public universities in Malaysia: A 
national study. Eur J Dent Educ 2020;24(1):163-8.

25. Gilmour ASM, Welply A, Cowpe JG, Bullock AD, Jones RJ. The undergraduate preparation of dentists: Confidence levels of final year dental students at the School of Dentistry in Cardiff. Br Dent $\mathrm{J}$ 2016;221(6):349-54.

26. Nieminen P, Virtanen JI. Information retrieval, critical appraisal and knowledge of evidence-based dentistry among Finnish dental students. Eur J Dent Educ 2017;21(4):214-9.

27. Straub-Morarend CL, Wankiiri-Hale CR, Blanchette DR, Lanning SK, Bekhuis T, Smith BM, et al. Evidence-Based Practice Knowledge, Perceptions, and Behavior: A Multi-Institutional, Cross-Sectional Study of a Population of U.S. Dental Students. J Dent Educ 2016;80(4):430-8.

28. Manakil J, George R. Self-perceived work preparedness of the graduating dental students. Eur J Dent Educ 2013;17(5):101-5.

29. Rodd HD, Farman M, Albadri S, MacKie IC. Undergraduate experience and self-assessed confidence in paediatric dentistry: Comparison of three UK dental schools. Br Dent J 2010;208(5):221-5.

30. Hunter $L$, Oliver R, Lewis R. The effect of a community dental service outreach programme on the confidence of undergraduate students to treat children: a pilot study. Eur J Dent Educ 2007;11(1):1013.

31. Coe JM, Brickhouse T, Bhatti B, Best A. Impact of Community-Based Clinical Training on Dental Students' Confidence in Treating Pediatric Patients. J Dent Educ 2018;82(1):5-11.

\section{Figures}




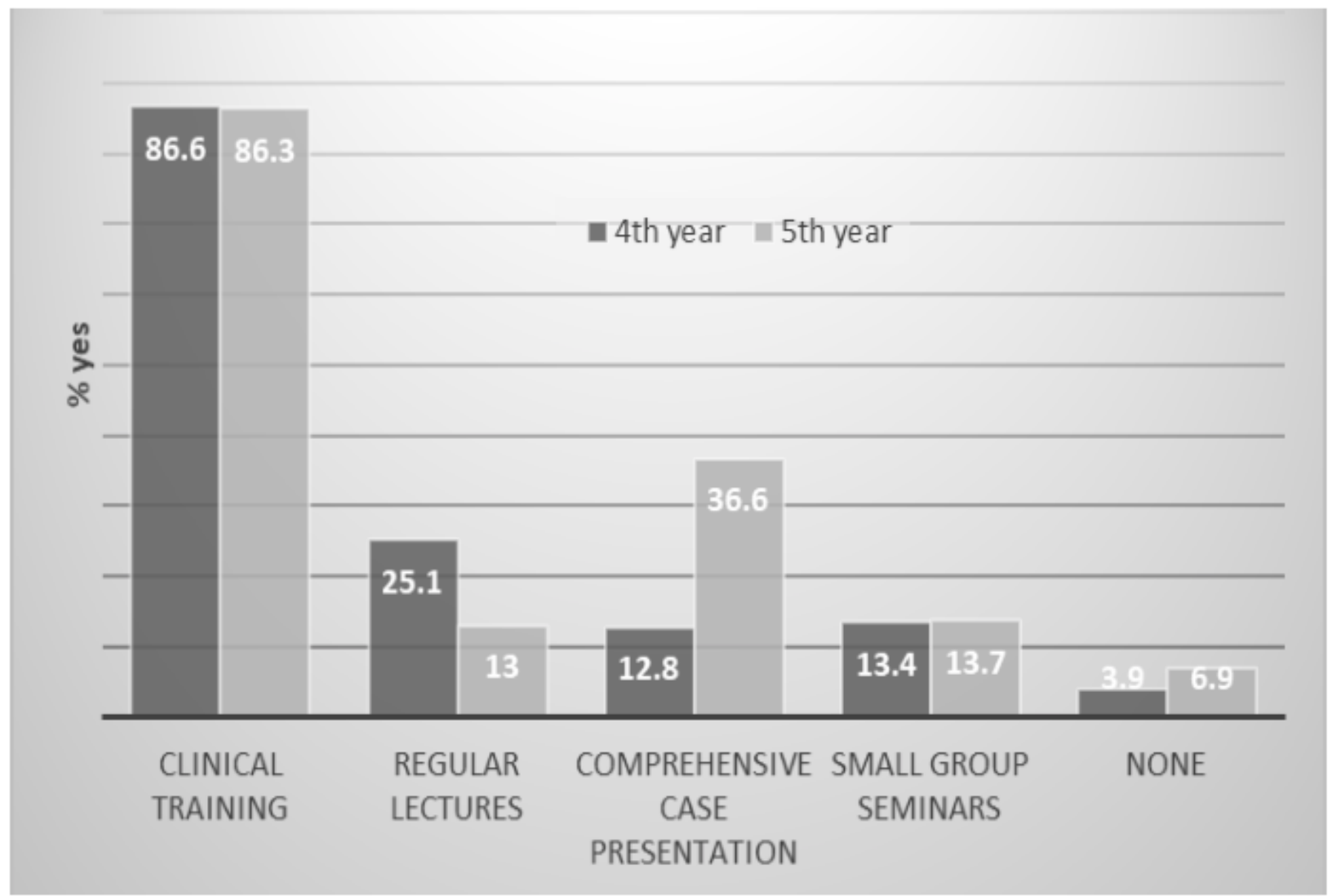

Figure 1

Experiences mostly affected by quarantine. 


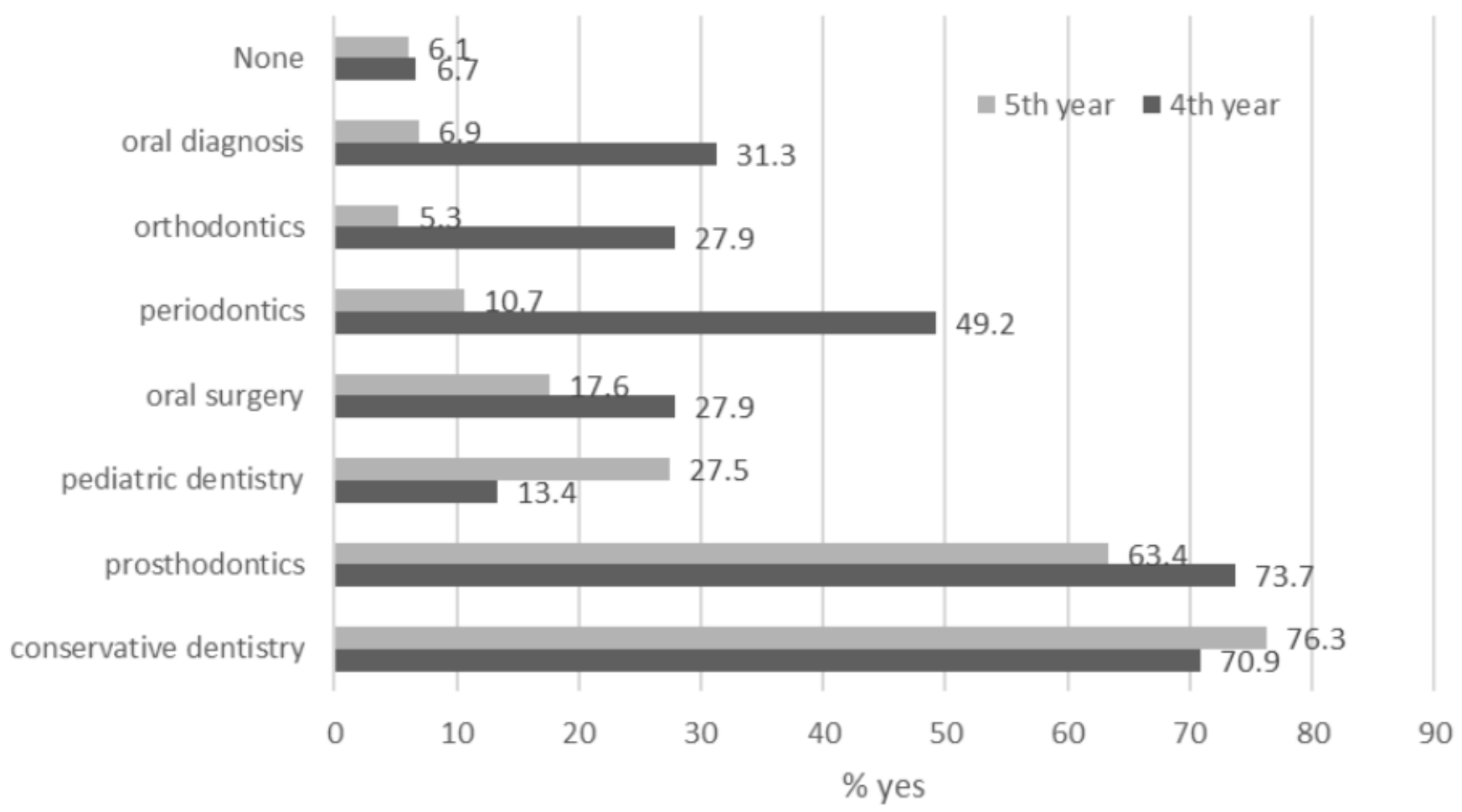

Figure 2

Dental subspecialties most negatively affected by quarantine. 